\title{
KAJIAN SASTRA PERJALANAN DALAM HIKAYAT KISAH PELAYARAN ABDULLAH KE MEKAH KARYA ABDULLAH BIN ABDUL KADIR MUNSYI
}

\author{
Yacub Fahmilda, Putri Zulikha \\ yacub.fahmilda@mail.ugm.ac.id \\ Universitas Gadjah Mada, Yogyakarta
}

\begin{abstract}
This research is aimed to identify and to reveal a hikayat as classic travel literature of Indonesia by the travel writing theory of Carl Thompson. To gain those purposes, this research used literary criticism and descriptive-analytic methods. The object of this study is Kisah Pelayaran Abdullah ke Mekah by Abdullah bin Abdul Kadir Munsyi (1854), focusing on the six elements of travel writing by Carl Thompson's approach based on the hikayat. This study shows that the hikayat contains six elements of travel writing. Those are self, other, movement, space, encounter, and writing. Abdullah as a sailor puts himself in his hikayat as the main character by using "sahaya" and "aku" to articulate "self" in his hikayat. The "self" during travel met new and foreign things that the author had never seen before. He drew and expressed his point of view, feeling, and observation of all the encounters that he had met during sailing in to hikayat.
\end{abstract}

Keywords: Carl Thompson; hikayat; travel writing

Karya sastra sebagai dunia imajinatif pengarang sangat dipengaruhi oleh berbagai faktor. Salah satu faktor tersebut adalah latar belakang pengalaman hidup pengarang. Dari pengalaman pengarang tersebut, penulis menuangkannya ke dalam bentuk karya, yang salah satunya adalah karya sastra atau karya fiksi. Hal itu diperkuat oleh pernyataan Pujiharto (2012: 19) bahwa karya fiksi dianggap sebagai manifestasi pengalaman kemanusiaan. Namun demikian, karya sastra sebagai catatan peristiwa pengarang sarat dengan persoalan akurasi, yaitu terkait fiksi dan fakta.

Persoalan fiksi dan fakta menjadikan suatu karya sulit untuk diklasifikasikan. Misalnya, karya sastra yang mengandung unsur-unsur fakta sosial seperti waktu, tempat, dan peristiwa mengindikasikan bahwa karya tersebut memuat kenyataan dan jauh dari hal-hal fiksional. Sementara itu, dalam beberapa karya sastra seperti Pelukis Padang Pasir - Fuad Abdurahman, Akar - Dee Lestari, 99 Cahaya Langit di Eropa Hanum Salsabila Rais, dan Edensor - Andrea Hirata sebagai karya imajinatif telah memuat latar tempat dan pelaporan peristiwa yang mengindikasikan karya tersebut nyata atau benar-benar terjadi. Hal tersebut sejalan dengan Teeuw (2015: 171) yang 
menyatakan bahwa dalam puisi Cina seni sastra harus meneladani tata semesta, kebenaran kesejarahan, dan kebenaran kemanusiaan. Berdasarkan pernyataanpernyataan di atas, karya sastra tidak hanya berupa dunia imajiner pengarang atau fiktif belaka, tetapi juga mengandung unsur-unsur fakta sosial yang meneladani tata semesta, kebenaran kesejarahan, dan kebenaran kemanusiaan.

Karya sastra yang memuat latar tempat dan pelaporan peristiwa dalam karya sastra merupakan catatan pengarang dalam bentuk narasi fiksional, yang disebut oleh Carl Thompson sebagai sastra perjalanan (travel writing). Menurut Thompson (2011:14), karya sastra perjalanan merupakan naratif yang menjadi cermin pengalaman pengarang dalam melakukan perjalanan, baik mengunjungi tempat, benda, ataupun bertemu dengan orang baru. Pernyataan tersebut sejalan dengan Nasution (2015:22) yang menyatakan bahwa karya sastra yang berupa aktualisasi dari catatan hasil perjalanan menawarkan sebuah narasi dari peristiwa-peristiwa yang terjadi selama perjalanan pengarangnya. Terlebih lagi, tulisan naratif tersebut membawa aspek personal, yaitu asumsi dan subjektivitas pengarang. Dalam hal ini, pengarang tidak sebatas menuliskan runtutan perjalanan waktu, tempat, dan peristiwa. Akan tetapi, pengarang juga melukiskan kesan atau respons terhadap tempat, impresi, pikiran, dan perasaan saat melakukan perjalanan.

Dalam hal genre sastra, semua jenis karya sastra, baik berupa puisi, drama, maupun prosa, dapat dikategorikan sebagai sastra perjalanan selama memenuhi beberapa indikator. Menurut Thompson (2011:14), indikator utama tersebut adalah terdapat suatu perjalanan untuk berpindah tempat dan melaporkannya dalam bentuk teks naratif sebagai pelaporan informasi atau penggambaran dunia berdasarkan pikiran penulis. Sehubungan dengan hal itu, hikayat sebagai karya sastra klasik dapat dikategorikan sebagai sastra perjalanan selama memenuhi indikator yang ada.

Menurut teori sastra perjalanan Thompson (2011), ada enam alat yang dapat digunakan untuk membedakan sastra perjalanan dengan karya sastra berjenis lain, yaitu self (diri), others (liyan), movement (perpindahan), space (ruang), encounter (pertemuan), dan writing (penulisan). Keenam alat tersebut merupakan seperangkat teori dasar untuk mengidentifikasi suatu karya sastra masuk dalam kategori genre sastra 
Yacub Fahmilda dan Putri Zulikha, Kajian Sastra Perjalanan dalam Hikayat Kisah Pelayaran Abdullah Ke Mekah Karya Abdullah bin Abdul Kadir Munsyi

perjalanan atau tidak. Dalam penelitian ini, keenam alat tersebut akan digunakan untuk mengkaji hikayat Kisah Pelayaran Abdullah ke Mekah.

Dalam buku Karya Lengkap Abdullah bin Abdul Kadir Munsyi karya Amin Sweeney, terdapat dua suntingan hikayat yang mencatat peristiwa dan perjalanan Abdullah. Dua naskah yang telah disunting tersebut berjudul Kisah Pelayaran Abdullah ke Kelantan dan Kisah Pelayaran Abdullah ke Mekah. Kedua naskah hikayat Abdullah tersebut memuat pelaporan peristiwa perjalanan sekaligus memuat impresi atau kesan tempat dan orang-orang yang baru dikunjunginya.

Dalam penelitian Yuliasari (2013:86), Kisah Pelayaran Abdullah ke Kelantan menggambarkan impresi atau stereotip masyarakat terhadap tempat baru. Ia mengelompokkan impresi tersebut menjadi empat belas bagian, yaitu stereotip tentang keadaan fisik, karakter, tempat tinggal, kebersihan lingkungan dan kesehatan, kebiasaan-kebiasaan, kebodohan, irasional, tidak menghargai bahasanya, tidak menghargai waktu, perempuan, dan perilaku-perilaku buruk pemimpin bangsa Melayu. Meskipun Abdullah keturunan orang Melayu, darah bangsa Arab dan pijakannya di tanah Melayu Kelantan menjadikan dirinya sebagai sosok yang superior atau berkedudukan sosial lebih tinggi. Penelitian Yuliasari tersebut memungkinkan adanya penggambaran dunia oleh Abdullah dalam hikayatnya yang lain.

Sementara itu, Kisah Pelayaran Abdullah ke Mekah merupakan catatan perjalanannya dari Singapura ke Mekah untuk berhaji. Secara kodikologis, pembahasan edisi dan deskripsi hikayat Kisah Pelayaran Abdullah ke Mekah mengacu pada informasi dari Amin Sweeney. Objek penelitian ini menggunakan suntingan teks yang dikerjakan dan dipublikasi oleh Amin Sweeney. Berdasarkan informasi Sweeney (2005), terdapat tiga varian naskah Kisah Pelayaran Abdullah ke Mekah. Naskah dasar yang disunting oleh Sweneey mengacu pada kode MS. W215 yang tersimpan di Perpustakaan Nasional Republik Indonesia, Jakarta. Adapun dua naskah lain adalah Kl. 63 dan Edisi Cap Batu dari majalah Cermin Mata. Sweeney (2005) berpendapat bahwa naskah kode MS. W215 dianggap memiliki kredibilitas tinggi karena tidak banyak teks yang diedit atau dihilangkan. Hal tersebut memperkuat penelitian ini dengan cukup 
menggunakan edisi suntingan teks daripada melakukan penyuntingan ulang secara mandiri.

Perjalanan menuju Mekah tersebut tidak terlepas dari pertemuan-pertemuan dengan tempat, orang, dan kebudayaan yang baru. Pertemuan-pertemuan dalam hikayat tersebut tampak memberikan kesan atau impresi yang kurang lebih serupa dengan hasil penelitian Yuliasari.

Sehubungan dengan objek penelitian, pengkajian sastra perjalanan baik kontemporer maupun klasik dengan pendekatan Thompson tidak banyak dihasilkan. Hal tersebut sesuai dengan pendapat Ekasiswanto (2017:44) bahwa teori sastra perjalanan belum banyak diaplikasikan daripada kajian poskolonial yang menjadi bagian dari kajian Thompson. Penelitian ini ditujukan untuk pengembangan keilmuan sastra Indonesia, khususnya pengkajian sastra klasik dengan teori sastra perjalanan kontemporer yang diharapkan dapat memberikan sumbangan sekaligus kebaruan dalam penelitian sastra perjalanan Carl Thompson.

Hikayat Kisah Pelayaran Abdullah ke Mekah merupakan sastra Melayu lama atau klasik karena terdapat beberapa hal yang mencirikannya. Menurut kajian Liaw (2016:179), semua penulisan pada sastra zaman peralihan Hindu-Islam berjudul hikayat karena kata tersebut berasal dari Arab yang artinya cerita. Selanjutnya, sastra Melayu klasik ditulis menggunakan Jawi, yaitu aksara Arab untuk menulis bahasa Melayu. Kedua ciri tersebut sesuai dengan hikayat Kisah Pelayaran Abdullah ke Mekah yang menjadi objek kajian ini. Namun demikian, Liaw juga menegaskan bahwa sastra Melayu klasik pada umumnya tidak mencantumkan tanggal penulisan atau penyalinan, bahkan nama pengarangnya. Di lain pihak, hikayat Kisah Pelayaran Abdullah ke Mekah mencantumkan tarikh penulisan dan pengarangnya. Hal tersebut dianggap oleh sarjana Barat dalam pengkajian hikayat Abdullah sebagai tanda peralihan sastra Melayu klasik menuju sastra modern. Konsep penulisan atau penerbitan sekaligus kepengarangan mulai diperkenalkan melalui tulisan Abdullah.

Pemilihan objek materi berupa hikayat dalam penelitian ini dilatarbelakangi oleh beberapa hal. Pertama, penulisan hikayat pada umumnya hanya menarasikan kisah perjalanan Dunia Melayu yang hari ini dikenal dengan Asia Tenggara. Berdasarkan hikayat ini, penulis melakukan perjalanan dari Singapura menuju Mekah. Kedua, Copyright @ 2021 Yacub Fahmilda, Putri Zulikha 
Yacub Fahmilda dan Putri Zulikha, Kajian Sastra Perjalanan dalam Hikayat Kisah Pelayaran Abdullah Ke Mekah Karya Abdullah bin Abdul Kadir Munsyi

hikayat tersebut ditulis prakemerdekaan Indonesia pada tahun 1850-an sehingga akan memberikan pengetahuan mengenai perjalanan dan kondisi beberapa tempat pada masa lalu berdasarkan pikiran dan pengalaman pengarang. Ketiga, Abdullah disebut sebagai penulis "sastra Melayu modern" yang telah memulai konsep "kepengarangan" dalam tradisi penulisan karya sastra Melayu klasik. Sebagai bapak sastra Melayu modern, Van der Putten (2006:407) juga mengatakan hal serupa. Kepengarangan tersebut memberikan otoritas terhadap hikayat karena memiliki autentisitas yang lebih akurat dibanding hikayat atau sastra Melayu klasik lain yang ditulis secara anonim.

Berdasarkan uraian di atas, dirasa perlu adanya pembuktian melalui analisis bahwa hikayat Kisah Pelayaran Abdullah ke Mekah mengandung enam alat indikator sastra perjalanan yang diuraikan oleh Carl Thompson atau tidak. Untuk mendeskripsikan sastra perjalanan pada suntingan hikayat tersebut, diperlukan analisis mendalam dengan pendekatan teori sastra perjalanan Carl Thompson.

\section{KAJIAN TEORETIS}

Thompson (2011:9-10) mendefinisikan sastra perjalanan sebagai negosiasi antara diri dan liyan yang diakibatkan oleh perpindahan melalui ruang yang kemudian dipahami sebagai laporan dunia luas, meliputi orang dan tempat asing. Dalam menganalisis karya sastra perjalanan, Thompson (2011) memiliki enam alat yang saling berhubungan dan tidak dapat dipisahkan, yaitu self (diri), others (liyan), movement (perpindahan), space (ruang), encounter (pertemuan), dan writing (penulisan). Keenam alat untuk meneliti hikayat ini dapat dijelaskan lebih detail sebagai berikut.

Posisi pengarang dalam suatu cerita menjadi hal yang penting, yaitu penggambaran citra diri pengarang dan tokoh 'aku' dalam cerita. Pengarang dalam cerita dapat terlibat secara langsung dengan memosisikan diri dengan menggunakan sudut pandang orang pertama. Citra diri dalam penggambarannya disebut sebagai selffashioning yang memosisikan diri untuk mengidentifikasi dan mengamati dunia yang lebih luas (Thompson, 2011:99).

Sementara itu, Thompson menegaskan (2011:103) bahwa konsep diri sangat lekat kaitannya dengan aspek zaman dan budaya sehingga citra diri dan lingkungan 
pengarang dalam perjalanan akan tampak secara antropologis dan historis. Hal tersebut serupa dengan pendapat Purwaningsih (2015:53) bahwa dalam konteks kolonialisasi bangsa Eropa, beberapa literatur penjelajahan, utopia imajiner, pelayaran, dan laporan dengan pendekatan ilmiah yang ditulis oleh bangsa Eropa dapat memperluas dan memperdalam pengetahuannya terhadap Timur. Melalui pelayaran yang bertahap dan pembacaan catatan perjalanan para pendahulunya, mereka makin memiliki gambaran jelas terhadap tempat yang mungkin mereka singgahi dan tuju.

Sebagai citra tandingan, diri akan menemui sosok liyan. Menurut Thompson (2011:122) liyan merupakan sosok yang digambarkan dan dinarasikan secara implisit. Hal tersebut berbeda dengan posisi diri atau self-author, baik superior maupun inferior, terhadap aspek kebudayaan diri dan liyan yang ditemui. Meskipun berada pada perjalanan di ruang yang sama dan sama-sama sebagai pejalan (tourist), diri pengarang akan menampakkan superioritasnya terhadap pejalan lain. Diri yang superior tersebut memiliki legitimasi untuk menulis atau mencatat segala hal, seperti liyan dalam satu ruang, yang disebut Thompson sebagai post-tourist (2011:126).

Sesuai dengan prinsip karya sastra yang telah diuraikan sebelumnya, yaitu berada di antara fakta dan fiksi, diri melihat liyan dengan dua kacamata. Kedua kacamata tersebut adalah subjektif dan objektif. Hal itu terjadi karena menurut Fussel dalam Holland dan Huggan (2000:9), sastra perjalanan paling baik dilihat sebagai mediasi antara fakta dan fiksi, yaitu merujuk pada orang, tempat, dan peristiwa aktual seperti yang ditemukan pengarang, tetapi pengarang secara bebas dapat menyelinginya dengan cerita yang diragukan kebenarannya. Cerita tersebut dapat berasal dari mitos atau sumber fiksi.

Diri dalam perjalanan senantiasa menarasikan perpindahan, yaitu mendetailkan laporan perjalanan pada aktivitas dan lokasi dari perpindahan (Thompson, 2011:75). Dalam pelaporan perpindahan ini, pengarang tidak berfokus pada diri, tetapi lebih menggambarkan aktivitas dan perpindahan selama perjalanannya. Misalnya, perpindahan dari satu aktivitas dan tempat menuju aktivitas dan tempat yang lain. Dalam hal ini, pengarang berfokus pada sesuatu yang dia lihat dan sesuatu yang dilakukan oleh liyan daripada menuliskan pikiran, impresi, atau kesan yang ditemuinya (Thompson, 2011:107). Perpindahan tersebut menunjukkan adanya globalisasi. Hal 
Yacub Fahmilda dan Putri Zulikha, Kajian Sastra Perjalanan dalam Hikayat Kisah Pelayaran Abdullah Ke Mekah Karya Abdullah bin Abdul Kadir Munsyi

tersebut ditandai oleh adanya kapal mesin yang menjadi pengangkut Abdullah dari Singapura menuju beberapa tempat hingga ke Mekah. Gagasan tersebut serupa dengan Putra (2018:244) yang menuturkan bahwa perjalanan internasional menjadi salah satu sebab dan bukti adanya globalisasi.

Perjalanan pengarang menuju suatu tempat tujuan biasanya menggambarkan pula secara naratif tempat-tempat persinggahan. Tempat persinggahan tersebut biasanya senantiasa terkait dengan tempat tujuan utamanya. Keterkaitan tempat persinggahan dan tempat tujuan utama merupakan keutuhan pengarang dalam membawa fokus ruang dalam cerita (Thompson, 2011:114). Keutuhan narasi pengarang dalam memandang ruang dalam cerita termasuk bagian dari perjalanan pengarang dalam menghadapi berbagai hal di luar dirinya. Ruang tersebut dapat meliputi keseluruhan aspek pejalan berada di alam yang berbeda.Ruang tercipta dari keberjarakan diri dengan liyan berdasarkan pengetahuan ataupun pengalaman pengarang sebelum melakukan perjalanan dengan hal baru yang ditemuinya di daerah yang dia singgahi. Ruang tersebut dapat berupa budaya, bahasa, makanan, dan berbagai hal lain yang menjadi media bagi diri untuk melakukan negosiasi dengan liyan.

Perpindahan dari satu ruang menuju ruang lain dengan aktivitas tertentu mempertemukan pengarang dengan diri dan liyan. Pertemuan tersebut membawa diri untuk bernegosiasi dengan lingkungan sekitarnya. Diri yang secara antropologis dan historis sebagai latar identitas pengarang harus bernegosisasi terhadap persamaan dan perbedaan atas ruang pertemuan tersebut (Thompson, 2011:9-10). Apabila semua perjalanan mempertemukan diri dan liyan melalui perpindahan, sastra perjalanan merupakan produk pertemuan untuk bernegosiasi. Beberapa dari hasil negosiasi antara diri dan liyan menciptakan pengalaman-pengalaman yang tidak dapat dilupakan begitu saja selama perjalanan. Hal itu menjadi salah satu alasan yang menggerakan orang untuk menulis hasil perjalanannya (Zulikha, 2019:2). Oleh karena itu, terbentuklah writing.

Menurut Ekasiswanto (2017:45), terdapat bias dalam writing karena secara sadar pengarang telah melakukan filterisasi terhadap peristiwa dan kejadian yang ditemui. Filterisasi tersebut disebabkan oleh transformasi dari "pengalaman perjalanan" menjadi 
“teks perjalanan" oleh penulis. Melalui "teks perjalanan” itu, pengarang melakukan penggambaran dunia (reporting the world) berdasarkan impresi, kesan, dan pengalaman yang subjektif. Subjektivitas tersebut dipertegas oleh Ekasiswanto (2017:45) bahwa penggambaran dan representasi dalam teks secara fungsional atau praktis memperlihatkan minat terhadap alam atau budaya yang diamati penulis.

Penulisan dalam sastra perjalanan menjadi media bagi penulis untuk menuliskan autobiografinya sekaligus bereksplorasi dengan pertanyaan terhadap identitas dirinya. Penulisan menurut Thompson (2011:114) dihadirkan atau ditulis pada saat sebelum dan/atau seusai perjalanan pengarang. Penulisan yang menghadirkan pertanyaan dan produksi penulisan secara terus menerus merupakan otoritas pejalan dalam menentukan sejarahnya (Thompson, 2011:99). Penulisan menjadi artikulasi pengarang dalam menuliskan perjalanan hidupnya, setidaknya bagian tertentu dari hidupnya tercatat dan menjadi bagian dari sejarah.

\section{METODE PENELITIAN}

Melalui disiplin ilmu sastra, penelitian ini menggunakan metode deskriptifanalitis untuk menganalisis sekaligus menyajikan pembahasan. Metode tersebut dilakukan dengan mengumpulkan kutipan-kutipan dari hikayat sebagai satuan data dan fakta dari objek kajian (Ratna, 2004:53). Adapun objek kajian yang digunakan berupa hikayat Kisah Pelayaran Abdullah ke Mekah. Hikayat tersebut sudah disunting oleh Amin Sweeney berdasarkan naskah kode MS. W215. Suntingan teks tersebut diterbitkan dalam seri buku Karya Lengkap Abdullah bin Abdul Kadir Munsyi Jilid 1 oleh Kepustakaan Populer Gramedia dan Ecole Francaise d'Extreme-Orient. Kutipankutipan dari hikayat tersebut diseleksi dan diidentifikasi untuk mendapatkan kutipan yang representatif.

Sebagai pisau analisis, penelitian ini menggunakan teori sastra perjalanan Thompson untuk meletakkan konteks hikayat Kisah Pelayaran Abdullah ke Mekahsebagai catatan, hikayat, atau cerita perjalanan pada masa pra-Indonesia. Penelitian ini hanya berfokus pada pengungkapan indikator sastra perjalanan Thompson dalam hikayat tersebut. Untuk mengungkap makna di balik hikayat, 
Yacub Fahmilda dan Putri Zulikha, Kajian Sastra Perjalanan dalam Hikayat Kisah Pelayaran Abdullah Ke Mekah Karya Abdullah bin Abdul Kadir Munsyi

diperlukan penelitian lebih lanjut sehingga dapat membuka peluang bagi peneliti lain untuk melakukan penelitian.

\section{HASIL DAN PEMBAHASAN}

Pada tarikh 29 Jumadil Awal 1279, yang berkorespondensi pada tarikh 1854 Masehi, Abdullah bin Abdulkadir Munsyi memulai perjalanan dari Singapura ke Mekah. Ia menaiki kapal yang bernama Subla's-salam milik Syaikh 'Abdul Karim untuk berangkat haji. Berbulan-bulan hidup di laut dan singgah di beberapa tempat, menjadikan hal yang baru dan asing bagi Abdullah perlu untuk dicatat.

Tahun 1800-an orang-orang nusantara ramai berhaji dengan kapal dan tidak banyak yang memberikan catatan kisah pada khalayak, kecuali melalui tuturan cerita selepas dari Mekah. Hal tersebut menurut Van den Berg (2010) menjadi daya tarik para muslim pada saat itu untuk berhaji dan belajar agama di Mekah. Terlepas untuk siapa catatan ini ditujukan pada saat itu, Abdullah berhasil memberikan manfaat pada pengkaji sastra pra-Indonesia melalui kisah perjalanan klasiknya. Pada bagian ini, penulis membahas mengenai cerminan enam alat sastra perjalanan berdasarkan teori Thompson dalam hikayat.

\section{Diri}

Abdullah bin Abdul Kadir Munsyi melibatkan diri ke dalam narasi catatan perjalanannya, yang berupa hikayat. Berdasarkan tuturan Sweeney (2006:224), Abdullah memiliki hubungan dekat dengan tokoh penting seperti Stamford Raffles, Wiliam Farquhar, Lady Sophia Raffless, dan Thomas Newbold yang tidak pernah disebutnya dalam berbagai tulisan. Akan tetapi, Sweeney menambahkan bahwa melalui tulisan-tulisannya, kita dapat memahami banyak tentang dirinya. Selain itu, kedekatan mereka kemungkinan saling memberikan pengaruh terhadap pengetahuan dan penulisan hikayat ini.

Dalam hikayat ini, Abdullah menyebut dirinya sebagai sahaya, sesuai dengan penggunaan aksara dan pelafalan bahasa Melayu klasik. Bila dipadankan dalam bahasa Melayu dan Indonesia, kata sahaya artinya 'saya, aku, atau beta'. Penyebutan diri ini 
menandakan bahwa Abdullah sebagai tokoh utama dalam catatan perjalanannya akan selalu ada dari awal hingga usai cerita.

...Bahwa ini peringatan sahaya berlayar dari negeri Singapura dalam kapal Syeikh 'Abdul Karim yang bernama Subla's-salam...(Sweeney, 2005:275)

Pengarang menyebut dirinya sebagai sahaya untuk mengartikulasikan diri dalam cerita. Sementara itu, Abdullah memberikan identitas lebih detail yang melekat pada tokoh sahaya sebagai pedagang yang bertujuan untuk berhaji ke Mekah.

...Sahaya ini orang dagang hendak pergi haji; singgah ke mari terlalu hairan melihat pekerjaan ini...(Sweeney, 2005:281)

Selain sahaya, Abdullah juga menyebut dirinya dengan kata $a k u$ dalam catatannya. Kata sahaya dan aku memang sepadan dalam bahasa Melayu dan Indonesia. Akan tetapi, kata tersebut memiliki referensi atau makna yang berbeda dalam penggunaannya. Kata sahaya biasa digunakan dalam kerajaan untuk menyebut diri ketika berhadapan dengan raja. Sementara itu, kata $a k u$ merujuk pada diri yang lebih bebas, setara, ekspresif, dan menampakkan ego. Selain itu, pemilihan kata sahaya dan kata aku berimplikasi pada pembentukan kata kepemilikan (possessive), seperti hatiku dan diriku. Apabila kata tersebut digunakan kata sahaya, hal itu akan memiliki makna yang berbeda. Secara gramatikal hal tersebut dapat diterima sehingga menjadi hati sahaya dan diri sahaya. Namun, pembentukan kata tersebut tidak lazim digunakan.

...Maka apabila aku melihat perbuatan akan masjid dan kolam itu, terlalulah 'ajaib dalam hatiku, sebab berfikirkan dapatiada jikalau barang siapa membaca akan kitab ini kemudian, maka ia kelak hendaklah mengetahuinya, siapakah yang telah membuat pekerjaan itu. Maka sebab itu kuusahakanlah diriku mencari akan rahsia itu... (Sweeney, 2005:281)

Apabila dibandingkan ketiga kutipan di atas, penggunaan kata sahaya dan $a k u$ memanglah berbeda. Perbedaan tersebut disebabkan adanya konteks dalam menarasikan diri. Abdullah menggunakan kata sahaya dengan dua kondisi yang berbeda. Pertama, Abdullah menulis sahaya pada awal kalimat atau pembuka hikayat. Dalam penulisannya, Abdullah menggunakan kata sahaya hingga akhir cerita tiba di 
Yacub Fahmilda dan Putri Zulikha, Kajian Sastra Perjalanan dalam Hikayat Kisah Pelayaran Abdullah Ke Mekah Karya Abdullah bin Abdul Kadir Munsyi

Judah (dibaca: Jeddah, Mekah). Hal tersebut merupakan bentuk penghormatan terhadap pembaca sehingga penulis dengan segala kekurangan dan keterbatasan pengetahuan merendahkan dirinya. Selanjutnya, kata sahaya digunakan ketika ia berjumpa dengan Serang Muhammad sebagai penduduk lokal ketika Abdullah merasa kagum pada suatu bangunan di sana. Ia ingin mengetahui lebih terperinci megenai suatu masjid dan kolam yang amat besar dan ia kagumi.

Sementara itu, Abdullah menggunakan kata $a k u$ ketika ia menggambarkan objekobjek yang ditemuinya. Penggambaran tersebut merupakan bentuk kebebasan berekspresi dalam memberi impresi terhadap pertemuannya dengan hal baru dan asing. Sehubungan dengan hal tersebut, penyebutan diri dalam catatan perjalanan Abdullah kontekstual terhadap hal-hal kultural. Selain itu, penyebutan diri dalam catatan perjalanan ini penting untuk diperhatikan karena mengandung makna yang berbeda.

Penggambaran diri dalam hikayat ini tidak lepas dari watak, karakter, kemampuan, dan kekhasan yang dimiliki tokoh. Dalam hikayat, Abdullah sebagai citra diri pengarang melalui tokoh utama dalam cerita digambarkan sebagai pedagang yang hendak berhaji lalu membuat catatan terhadap kondisi dan sejarah tempat yang disinggahinya. Adapun catatan tersebut dapat berbagai bentuk, seperti catatan agenda perjalanan atau peta. Kedua bentuk tulisan tersebut tentu memberikan gambaran kepada pembaca terhadap fenomena yang telah ia temui.

...Maka air yang di pelabuhan itu seperti air di dalam dulang, tenang sekali. Maka kelihatanlah negeri Judah itu dari jauh terlalulah bagus rupanya. Maka pada masa itu adalah sebatang pensel di tanganku. Maka kata nakhodahnya: "Abdullah, inilah waktu baik engkau tulis peta negeri Judah ini; maka kalau ad aangin atau ribut tiada boleh kelihatan terus". Maka naiklah aku ke atas jali-bot; lalu kutulislah seperti yang di atas itu...(Sweeney, 2005:291)

Abdullah juga mendokumentasikan perjalanannya dalam bentuk peta. Seorang nakhoda menyarankan Abdullah untuk menggambar Juddah dan ia naik ke jali-bot. Hal tersebut menggambarkan diri seorang pejalan adalah orang yang berjiwa seni. Selain memiliki kemahiran dalam bercerita lisan dan tulisan, ia mampu melukiskan bentang alam suatu tempat berupa gambar peta.

\section{Liyan}


Perjalanan Abdullah menaiki kapal telah mempertemukan kehidupan yang baru, asing, dan berbeda bagi dirinya. Terlebih lagi, perjalanan tersebut memakan waktu yang cukup lama sehingga Abdullah dapat melihat, mengamati, dan mengimpresi halhal di sekitarnya. Selama pelayaran, ia bertemu dengan para pedagang dan penumpang dari berbagai daerah yang sama-sama hendak berhaji. Sosok yang secara otomatis ia sebutkan adalah orang-orang yang mengambil peran penting dalam pelayarannya ini, yaitu nakhoda dan mualim yang bertugas untuk menjaga kapal dari berangkat, selama perjalanan, hingga sampai tempat tujuan.

...Maka dengan beberapa hemat dan ikhtiar nakhodah dan mu'alim, maka lepaslah kapal itu masuk ke dalam bab(dibaca: gerbang) itu....(Sweeney, 2005:284)

Namun demikian, kebanyakan liyan dalam hikayat ini tidak dideskripsikan secara mendalam, baik bentuk fisiknya maupun sifatnya. Sering kali, orang-orang tersebut hanya ditulis namanya sebagai keterangan penjelas saja. Jika pun dideskripsikan, Abdullah hanya menuliskannya secara umum, seperti sifat kuli yang ditemuinya. Ia mengamati bahwa kuli di tempat tujuan memiliki karakter kasar. Penggambaran buruk para kuli tersebut sangat jelas digambarkan saat tiba di pelabuhan Judah.

...Kuli2 pun beratus2 berkerumun. Maka diangkatnya satu barang, dibawanya ke hadapan orang yang menerima cukai itu. Maka lambat dibuka peti dipecahkannya dan barang ikatan dipotongnya dan dikoyakkannya dengan kelakuan yang terlalu kekasaran, tiada dapat ditegahkan lagi; barang sukanya dibuatnya sahaja. Maka katanya "Ini bayar sekian, itu sekian." Barang katanya itulah dia; ada yang pakaian dipakai pun dicukainya, ada yang tiada di cukainya, melainkan barang katanya itulah sahaja, tiada lagi boleh ditanya dan dipinta dan diketahui berapakah 'adatnya...(Sweeney, 2005:291-292)

Selain sosok kuli dan nakhoda, liyan yang digambarkan juga dapat berupa bangunan terutama rumah dan masjid, kondisi alam sekitar, tumbuhan, budaya, bahkan sejarah daerah yang disinggahinya. Persinggahan Abdullah cukup lama di negeri Alfiah. Hal tersebut membuat dia memiliki banyak waktu untuk mengelilingi dan mengeksplorasi tempat tersebut. Penggambaran negeri Alfiah tersebut tampak pada kutipan berikut.

...Maka adalah masjid dalam negeri Alfiah itu sahaja sepuluh. Maka tiga buah masjid sahaja yang berjama'ah. Maka adalah suatu sungai air tawar yang boleh mudik lima belas hari. Maka dalam sungai itulahyang terlalu banyak ikan dan hudang galah. Adapun binatang yang dalam hutannya itu gajah dan harimau dan badak dan babi hutan dan rusa, kijang, pelanduk dan anjing hutan serigala. Maka ularlah terlalu banyak, ada yang terlalu besar2. Maka burung2nya terlalu banyak jenis2nya, yaitu merak dan berbagai2 
Yacub Fahmilda dan Putri Zulikha, Kajian Sastra Perjalanan dalam Hikayat Kisah Pelayaran Abdullah Ke Mekah Karya Abdullah bin Abdul Kadir Munsyi

burung2, tetapi burung yang kebanyakan dalam neegri itu burung gagak, seperti lalat dalam rumah.... (Sweeney, 2005:278)

Melalui penggambaran negeri Alfiah, dapat dipahami bahwa Abdullah memiliki ketertarikan pada banyak hal baru dan asing selama perjalanan. Melalui catatannya, pembaca dapat membayangkan situasi tempat tersebut dan mengetahui apa saja yang ada di sana. Pada persinggahan lain, Abdullah juga menggambarkan sosok liyan ketika sampai di negeri Mukha.

...Maka serta sampailah aku ke darat, maka masuklah ke dalam pintu yang di sebelah laut, lalu berjalanlah berkeliling2 negeri itu. Maka sebesar2 'ajaiblah rasanya dalam hatiku, sebab mleihatkan hal perbuatan rumah2 mereka itu besar2 serta dengan elok2 perbuatannya. Sekaliannya rumah2 itu bertingkap2; maka sekalian tingkapnya itu berukir dan kaluk dengan berbunga2 terlalu eloknya. Akan tetapi dalam seratus rumah tiada sepuluh buah yang ada berbangku, semuanya habis kosong dan yang ada separuh roboh dan yang ada terkunci. Adapun sebuah2 rumahnya itu kira2 boleh diduduki oleh seratus dan yang ada lima enam puluh orang. Maka tiadalah yang dilihat rumah yang kecil2 dalam negeri itu, melainkan ada yang di luar2 negeri. Maka sekaliannya rumah2 itu tiada yang bergenting, semuanya bersotoh. Dan lagi temboknya terbalnya sebelah2 dada serta dengan teguhnya.....

...Maka adalah kelakuannya negeri itu seperti negeri tinggal, sunyi tiap2 kedai2 dan pasarnya, melainkan pada sedikit tempat, itu pun pada petang2 orang berkampung berjualan barang2 dan sebagainya. Maka kampung kedai saudagar2nya itu pun demikian, empat lima yang terbuka, lima enam kedai yang tertutup; terlalulah hairan dalam hatiku sebab melihatkan hal yang demikian. Maka aku pun tinggalah dua tiga malam di darat, sebab hendak mengetahui akan hal rahsia negeri itu....(Sweeney, 2005:286)

Dalam menggambarkan liyan, Abdullah lebih cenderung menggunakan sisi objektif daripada sisi subjektif. Abdullah sangat sedikit mengikutsertakan ekspresi dirinya serta lebih banyak narasi yang informatif dan berisi fakta. Pada kutipan di atas, Abdullah dengan detail menggambarkan kondisi dan situasi negeri Mukha. Sehubungan dengan kondisi tersebut, ia justru berusaha menyelidiki tempat itu lebih jauh sehinga perlu untuk bermalam dan mencari penduduk setempat yang bisa dimintai keterangan.

Penggambaran terperinci, apa adanya, dan mengesampingkan impresi membuat pembaca yakin bahwa perjalanan tersebut benar-benar dilakukan. Selain itu, penggambarannya yang apa adanya sehingga mengesampingkan kesan-kesan terhadap liyan tersebut menandakan bahwa penulis mengambarkan dunia baru dan 
asing tersebut dengankecenderungan pada sisi objektif, tapi tidak berarti lepas secara penuh dari subjektivitas. Terlebih lagi, ia berusaha menghindari asumsi-asumsi terhadap tempat tersebut sehingga perlu adanya pengamatan dan penggalian informasi lebih lanjut kepada penduduk lokal. Hal-hal tersebut menandakan bahwa catatan perjalanan Abdullah memuat pertemuan-pertemuan dengan liyan yang berupa orang, tempat, tumbuhan, bangunan, dan sejarah.

\section{Perpindahan}

Dalam hikayat ini, perjalanan yang ditempuh oleh Abdullah sangatlah jauh dan bersinggah di banyak tempat. Perpindahan yang dilakukan Abdullah dari Singapura ke Mekah melewati berbagai pulau dan negeri sesuai kapal berlabuh. Jika ada tempat yang membuat harinya tertarik, ia akan mencoba untuk berkeliling mengitari tempat-tempat di suatu negeri yang dianggapnya unik. Tidak jarang dalam catatannya, ia pun memilih untuk bermalam beberapa hari guna mencari informasi lebih lanjut mengenai tempat tersebut pada penduduk setempat. Dari catatan Abdullah, peneliti telah mengumpulkan alur tempat-tempat yang disinggahi oleh kapal yang dinaikinya. Berikut rutenya.

Titik pemberangkatan dari Singapura $\rightarrow$ Laut Melaka $\rightarrow$ Laut Pinang $\rightarrow$ Pulau Perak $\rightarrow$ Jajahan Tanah Aceh $\rightarrow$ PulauSailan $\rightarrow$ Gali $\rightarrow$ Bertentangan dengan Gunung Sailan $\rightarrow$ Kep. Gamri $\rightarrow$ Negeri Alfiah $\rightarrow$ ganti kapal ke Koci $\rightarrow$ Suakadu $\rightarrow$ Punakai $\rightarrow$ Tanur $\rightarrow$ Yalaturu $\rightarrow$ bandar Kalikut $\rightarrow$ Pulau Sokotra $\rightarrow$ Pulau 'Abdul Kuri $\rightarrow$ ganti ke kapal Inggris hingga bertentangan dengan 'Adnan $\rightarrow$ Bab Iskandariah $\rightarrow$ Labuhan Mukha $\rightarrow$ Negeri Mukha $\rightarrow$ Hudaidah $\rightarrow$ Lamlam $\rightarrow$ Judah $\rightarrow$ sampai di Mekah.

Perpindahan Abdullah tampak pada setiap pergantiannya menaiki kapal yang berubah-ubah. Hal tersebut memberikan kekhasan terhadap catatan perjalanannya bahwa hikayat ini benar-benar merupakan catatan klasik pelayaran di masa lampau. Menurut Baihaqi (2016), pada zaman dahulu, pelayaran haji dari nusantara ke tanah Hijaz ditempuh dengan kapal-kapal layar niaga milik domestik atau orang asing, seperti orang-orang Arab. Hal tersebut nampak pada beberapa nama kapal dan pemilik yang ditumpanginya. Misalnya, kapal Subla's-salam milik Syeikh 'Abdul Karim, kapal Fathul-mubarak milik Nakhoda Haji 'Ali bun Ahmad bin 'Isa, dan kapal bernama 'Atia Rahman miliki Muhammad Gohtan. 
Yacub Fahmilda dan Putri Zulikha, Kajian Sastra Perjalanan dalam Hikayat Kisah Pelayaran Abdullah Ke Mekah Karya Abdullah bin Abdul Kadir Munsyi

...Maka dengan tolongan Allah maka datanglah sebuah kapal dari Kalkatah yang bernama 'Atia Rahman, nakhodanya bernama Muhammad Tamim; yang empunya kapal itu Muhammad Gohtan yang diam di negeri Hudaidah. Adalah ia membawa orang Benggala yang hendak pergi haji, banyaknya seratus lima puluh orang laki2 dan perempuan serta kanak2. Maka pergilah kami sekalian hendak menumpang di kapal itu pergi ke Judah....(Sweeney, 2005:279)

Berdasarkan kutipan tersebut, Abdullah mengalami perpindahan yang sangat signifikan dari Singapura dengan kapal Subla's-salam milik Syeikh 'Abdul Karim hingga akhirnya sampai di Mekah dengan kapal 'Atia Rahman milik Muhammad Gohtan dari Hudaidah.

Perpindahan Abdullah juga mencatat perubahan cuaca dan kondisi laut selama berlayar. Segala hal hambatan yang dihadapi, juga ia tulis sebagai tanda perpindahannya. Perpindahan yang membawanya pada persinggahan sejatinya menuju Mekah untuk berhaji. Pengarang menarasikannya dengan setia, tampak pada awal mulai hingga akhir cerita. Perpindahan tersebut mendapati pengamatan terhadap kondisi persinggahan sejak awal hingga ia sampai di tujuan utama.

...Maka dengan hal yang demikian angin pun teduhlah sehingga diberi Allah sampailah ke Lamlam, yaitu tempat orang2 haji memakai ihram. Maka beranyut2lah kapal itu. Maka sampailah petang. Maka setelah esok hari maka kelihatanlah negeri Judah itu, akan tetapi kapal itu tiadalah berani dekat....(Sweeney, 2005:290)

Abdullah telah sampai ke negeri Lamlam untuk berhaji di Mekah. Menurut Baihaqi (2016), pelayaran Abdullah berhaji dengan kapal pada masa itu memerlukan waktu sekitar tiga bulan. Hal tersebut serupa pada kajian Sweeney (2005:299-303) yang mencatat kronologi tarikh, hari, dan tempat berdasarkan teks. Pencatatan dimulai dari Singapura pada 29 Jamadi'l-awal, 1270/ 27 Februari 1854 yang seharusnya 29 Rabi'u 'l-akhir 1270 sehingga berkorespondensi dengan 29 Januari 1854. Sweeney (2005:299) mencatat bahwa Abdullah sampai di Judah pada Jumat, 7 Sya'ban 1270 berkorespondensi dengan 5 Mei 1854. Setelah beberapa hari di Judah, ia berangkat ke Mekah. Perpindahan ini menandakan secara signifikan bahwa Abdullah dengan cermat menulis tempat penting untuk persinggahan dan pergantian kapal tanpa meninggalkan kronologis waktu dalam pelayarannya.

\section{Ruang}


Pengamatan Abdullah dalam perjalanannya tidak seutuhnya memberikan impresi atau kesan terhadap suatu tempat karena liyan digambarkan cenderung lebih objektif. Abdullah hanya mengikutsertakan impresinya pada ruang tertentu yang dilaluinya. Ruang tersebut hadir karena adanya pertemuan antara diri yang tidak bisa terlepas dari latar belakang tokoh Abdullah dan sosok liyan yang baru ditemuinya. Sosok yang digambarkan secara liyan erat kaitannya dengan latar belakang budaya Abdullah sebagai orang Melayu berketurunan Mesir. Ruang budaya tersebut membuat Abdullah juga menggambarkan masyarakat setempat saat hendak singgah di sekitar India, yaitu dengan memberikan stereotip terhadap penduduk.

...Maka segala perempuan2 Hindu yang berjalan itu semuanya tua mudanya bertelanjang juga, ya'ni tiada berbaju, kuntal-kantil saja. Maka adalah yang pertama2 menjadikan 'ajaib kepadaku sebab melihat 'adat orang dalam negeri itu, tiadalah menjadi 'aib bagi mereka itu segala perempuan2 beratus2 dan beribu2 semuanya bersusunya, baik yang muda baik yang tua; yaitu semuanya perempuan Hindu. Tetapi perempuan Islamnya bukannya demikian, bertutup kepala dan berbaju adanya...(Sweeney, 2005:280)

Hal yang distereotipkan merupakan pengaruh diri terhadap kondisi budaya dan agama liyan. Hal itu juga disebabkan oleh pengetahuan sebelumnya yang dimiliki oleh pejalan. Abdullah sebagai muslim memandang keberadaban manusia berdasarkan pada keimanannya dalam Islam. Menurut kutipan di atas, Abdullah menciptakan ruang terhadap budaya dengan memberikan penilaian. Seorang yang beriman memosisikan suatu budaya seharusnya selaras dengan perintah syariat atau hukum Islam. Dalam hal ini, pandangan diri sebagai muslim berkaitan erat dengan budaya dan pandangan terkait pemberadaban masyarakat.

Selain ruang budaya, ruang kembali muncul dari adanya produk makanan setempat. Seperti yang telah diuraikan sebelumnya, ruang meliputi segala hal akibat keberjarakan diri dengan liyan berdasarkan pengetahuan ataupun pengalaman pengarang sebelum dan sesudah melakukan perjalanan, termasuk makanan. Makanan dari daerah asal dengan yang ditemuinya di daerah yang disinggahi tentu saja memiliki perbedaan. Hal itu menciptakan ruang bagi diri untuk melakukan negosiasi dengan makanan yang baru dia temui setelah melakukan perjalanan, apalagi jika perbedaan itu sangat mencolok. Perbedaan harga makanan tempat asalnya membuat Abdullah heran dengan harga makanan yang begitu murah di negeri Kalikut dan Mukha. Kedua negeri 
Yacub Fahmilda dan Putri Zulikha, Kajian Sastra Perjalanan dalam Hikayat Kisah Pelayaran Abdullah Ke Mekah Karya Abdullah bin Abdul Kadir Munsyi

itu memberikan ruang pada Abdullah untuk menggambarkan kekhasan makanan di daerah tersebut.

...Adapun segala makanan terlalu murah: ayam satu du[a] sen satu rupia dan kambing yang besar2 seekor satu rupia sampai tengah dua rupia; telur tengah rupia seratus; dan beras tengah dua rupia satu man; kepala seratus satu rupia....Dan lagi seperti makanan murah juga, hampir2 seperti Mukha juga. ...(Sweeney, 2005:285-289)

Melalui penulisan Abdullah, catatan tersebut menggambarkan berbagai macam bentuk ruang yang dapat pembaca bayangkan. Tidak hanya mencatatnya, Abdullah sebagai pejalan juga memberikan impresi, kesan, dan subjektivitasnya pada hal-hal yang baru ditemuinya. Perbedaan latar belakang budaya, agama, ras, dan pengetahuan sebelum melakukan perjalanan pada diri Abdullah tampak pada gaya penulisannya yang memberikan penilaian terhadap ruang-ruang budaya dari masyarakat setempat. Dengan demikian, pejalan selalu dimungkinkan memiliki penilaian terhadap hal asing dan baru ditemuinya berdasarkan pengetahuan dan latar belakang pencatat perjalanan.

\section{Pertemuan}

Perpindahan diri dari Singapura menuju Mekah membuat diri bertemu dengan hal baru dan asing, yaitu kehidupan kapal dan laut. Pertemuan Abdullah dengan kehidupan baru tersebut dianggap sebagai sosok liyan yang senantiasa mendorongnya untuk beradaptasi. Ketika suatu tempat bersinggah terlalu rumit dan banyak rintangannya, ia beradaptasi dengan membaca salawat dan doa selamat. Hal tersebut merupakan cara seorang agamis dalam menghadapi hal-hal sulit dengan senantiasa menyertakan Allah, dalam hikayat ini hal sulit tersebut adalah kehidupan kapal dan laut yang tidak biasa ia alami. Kesulitan dan rintangan tersebut dianggap sebagai musuh yang harus dijinakkan, terlebih lagi musuh yang baru pertama kali ia temui.

Adapun adaptasi tersebut tampak pada saat Abdullah sampai di Lamlam, yaitu terdapat lorong-lorong karang yang menjadi rintangan untuk berlabuh. Pertemuannya dengan kehidupan di laut dinegosiasikan dengan latar belakang kepribadiannya yang agamis. Hal itu tampak pada kutipan berikut.

...Maka nakhodanya itu pun adalah berdiri serta dengan ketakutan. Maka orang sekaliannya pun tiadalah diberi bercakap2. Maka masing2 pun berdiamlah diri sambil 
meminta do'a daripada bahaya karang itu.Maka layat pun semuanya diturunkanlah sehingga tinggal empat layar. Maka air pun seperti dilontar derasnya masuk. Maka adalah kira2 tiga jam lamanya diberi Allah masuklah kapal itu dengan selamatnya dengan tiada suatu bahaya adanya. Maka pada masa itu baharulah tertawa nakhodanya serta sekalian orang yang di dalam kapal itu; maka baharulah membaca selawat tiga kali serta membaca doa selamat....(Sweeney, 2005:290)

Kutipan tersebut menampakkan bahwa Abdullah adalah seorang yang agamis. Hal tersebut juga masuk akal mengingat ia dan rombongan bertujuan untuk haji. Melalui kutipan tersebut, dapat dipahami bahwa menurut Abdullah segalanya merupakan kehendak dan pemberian Allah sehingga ia hanya bisa meminta dan berdoa. Pertemuannya terhadap hal baru dan asing ini ditanggapi dengan bagaimana ia seharihari mengamalkan diri dalam nilai-nilai islam. Nilai-nilai tersebut telah terinternalisasi pada alam pikiran Abdullah sehingga jika hal rumit dan mengancam serupa ditemuinya, secara otomatis alam pikiran Abdullah akan merespons demikian.

Pertemuan antara diri dan liyan juga membuat Abdullah merasa ingin tahu lebih pada liyan yang ditemuinya. Karena keingintahuan dan keheranannya, Abdullah sering kali mencari informasi mengenai liyan tersebut pada masyarakat setempat. Hal itu terjadi ketika Abdullah ingin tahu tentang daun yang dimakan oleh orang negeri Hudaidah serta pembuat masjid dan kolam di negeri Kalikut. Bahkan, rasa keingintahuan Abdullah membuat dirinya tinggal beberapa hari di tempat ia menjumpai liyan tersebut. Hal itu dilakukan oleh Abdullah ketika sampai di Mukha.

...Maka adalah kelakuannya negeri itu seperti negeri tinggal, sunyi tiap2 kedai2 dan pasarnya, melainkan pada sedikit, itu pun pada petang2 orang berkampung berjual barang2 dan sebagainya. Maka kampung kedai saudar2nya itu pun demikian, empat lima yang terbuka, lima enam kedai yang tertutup; terlalulah hairan dalam hatiku sebab melihatkan hal yang demikian. Maka aku pun tinggalah dua tiga malam di darat, sebab hendak mengetahui akan hal rahasia negeri itu. Maka aku jalanilah mengelilingi negeri itu. ...Syahdan maka aku pun bertanyakanlah akan hal negeri itu. ...(Sweeney, 2005:286)

Sebagai penulis catatan perjalanan, Abdullah memosisikan diri sebagai pendatang atau pejalan yang tidak banyak memberi judgement terhadap pertemuannya dengan liyan. Abdullah lebih memilih untuk melakukan penyelidikan lebih dalam terhadap fenomena baru yang ditemuinya. Ia berniat untuk mencari penduduk lokal untuk menerangkan kesejarahan tempat tersebut sehingga dapat ia tulis dalam 
Yacub Fahmilda dan Putri Zulikha, Kajian Sastra Perjalanan dalam Hikayat Kisah Pelayaran Abdullah Ke Mekah Karya Abdullah bin Abdul Kadir Munsyi

hikayatnya. Menurut pendapat Sweeney (2006:226) setelah melalui kajian mendalam, tulisan-tulisan Abdullah menampilkan suatu dunia yang realis. Melalui pertemuan dan penyelidikan tersebut, Abdullah juga menuliskan pelaporannya terhadap bentang alam, budaya, kehidupan laut, bangunan, dan kesejarahan yang sangat dekat dengan aspek historis dan antropologis.

\section{Penulisan}

Abdullah dalam hikayat ini memosisikan diri sebagai orang pertama pelaku utama. Artinya, penulis tidak melakukan penyalinan, penerjemahan, dan penyaduran. Abdullah secara langsung mengalami dan menuliskan catatan perjalanannya, baik setelah maupun selama perjalanan berlangsung. Terlihat bahwa pengarang menuliskan catatan perjalanannya karena ia terkesan pada sosok baru dan asing yang ditemuinya. Abdullah ingin agar pembaca hikayatnya mengetahui perihal negeri-negeri yang jauh, yaitu negeri-negeri yang pada abad ke-18 diidam-idamkan oleh penduduk nusantara yang ingin menunaikan haji sebagai penyempurna rukun Islam. Oleh karena itu, penggambaran liyan yang dilakukan sangat deskriptif dan objektif.

...Maka apabila aku melihat perbuatan akan masjid dan kolam itu, terlalulah 'ajaib dalam hatiku, sebab berfikirkan dapatiada jikalau barang siapa membaca akan kitab ini kemudian, maka iakelak hendaklah mengetahuinya, siapakah yang telah membuat pekerjaan itu. Maka sebab itu kuusahakanlah diriku mencari akan rahsia itu....(Sweeney, 2005:281)

Penulisan hikayat Abdullah dipengaruhi oleh kedekatannya dengan para kolonial Inggris terlebih posisinya sebagai asisten Thomas Raffles. Secara pembangunan cerita, Abdullah sudah menggunakan model yang sedikit mirip dengan roman atau novel. Hal yang signifikan dalam penulisannya adalah menggambarkan atau mengkisahkan sebuah perjalanan yang lebih rasional atau realis. Meskipun ada banyak tempat asing dan baru, ia tidak menarasikannya dengan mistis, supranatural, dan ajaib. Abdullah juga memberikan catatan tarikh dan tempat dengan jelas. Bahkan, ia mencantumkan dirinya dalam karya sehingga jauh dari tradisi sastra Melayu yang cenderung anonim.

Namun demikian, Abdullah menuliskan alur pelayarannya dengan cukup membingungkan. Hal ini disebabkan oleh beberapa tempat yang tidak ditulisnya secara 
terperinci dan pemfokusan pada penggambaran tempat-tempat tertentu saja, seperti Negeri Alfiah, Mukha, dan Juddah. Terlebih lagi, penulisan hikayat ini menggunakan bahasa pada zamannya sehingga memiliki keberjarakan kosakata dan gramatikal dengan pembaca berbahasa Indonesia sekarang ini. Dengan demikian, tulisan perjalanan Abdullah ini sangat otentik berupa perjalanan kisah klasik pada prakemerdekaan dan kolonialisme.

\section{SIMPULAN}

Berdasarkan pemaparan hasil dan pembahasan di atas, dapat disimpulkan bahwa hikayat Kisah Perjalanan Abdullah ke Mekah dapat didekati dengan indikator sastra perjalanan teori CarlThompson. Enam perangkat teori sastra perjalanan tersebut antara lain adalah diri, liyan, perpindahan, pertemuan, dan penulisan. Pengarang memosisikan diri sebagai tokoh utama melalui tokoh Abdullah yang dicitrakan dengan kata sahaya dan aku sebagai pedagang yang hendak melakukan perjalanan haji. Dalam perjalan tersebut, diri mengalami perpindahan dari Singapura ke Mekah dengan berpindah-pindah tempat. Ia singgah di berbagai pulau dan negeri. Perpindahan tersebut membuat diri bertemu dengan liyan. Pertemuan terhadap tempat dan hal baru, menciptakan ruang yang membuat diri memberikan kesan terkait adanya perbedaan kebudayaan, kepercayaan, dan makanan dari daerah asal dengan daerah yang disinggahi.

Pertemuan diri dengan liyan yang dilatarbelakangi oleh kebudayaan dan pengetahuan diri sebelum melakukan perjalanan sering kali memunculkan keingintahuan dan keheranan. Dari liyan-liyan yang membuatnya terkesan tersebut, pejalan terdorong untuk menulis catatan perjalanannya menjadi sebuah hikayat. Selain itu, pengarang banyak mendeskripsikan liyan secara objektif dan sesuai fakta dengan terperinci agar pembaca mengetahui dengan betul daerah-daerah yang telah disinggahi oleh Abdullah. Melalui penelitian ini, terbukti bahwa hikayat ini mengandung enam alat indikator sastra perjalanan Carl Thompson. Oleh karena itu, hikayat ini dapat dimasukkan dalam kategori sastra perjalanan. 
Yacub Fahmilda dan Putri Zulikha, Kajian Sastra Perjalanan dalam Hikayat Kisah Pelayaran Abdullah Ke Mekah Karya Abdullah bin Abdul Kadir Munsyi

\section{REFERENSI}

Baihaqi, A. F. (2016). Pelayaran angkutan jamaah haji di Hindia Belanda (Tahun 19111930). Buletin Al-Turas, 22(1), 1-24.

Ekasiswanto, R. (2017). Penggambaran dunia dalam The Naked Traveler 1 Year Round-The-World Trip karya Trinity: Analisis Sastra Perjalanan Carl Thompson. Semiotika, 18(1), 42-59.

Holland, P., \& Huggan, G. (2000). Tourists with Typewriters. The University of Michigan Press.

Liaw, Y. F. (2016). Sejarah Kesusastraan Melayu Klasik. Yayasan Pustaka Obor.

Nasution, A. A. (2015). Gambaran diri Andrea Hirata dalam Novel Edensor: Konsep Travel Writing Carl Thompson. Poetika, 3(1), 22-31.

Pujiharto. (2012). Pengantar Teori Fiksi. Ombak.

Purwaningsih, N. S. (2015). Subjektivitas dalam cerita perjalanan novel Lumbini karya Kris Budiman. Poetika, 3(1), 50-59.

Putra, C. R. W. (2018). Penggambaran dunia dalam sastra Exil : Kumpulan Cerpen Kera di Kepala karya Soeprijadi Tomodiharjo sebagai Cerita Perjalanan. 244 253.

Ratna, N. K. (2004). Teori, Metode, dan Teknik Penelitian Sastra. Pustaka Pelajar.

Sweeney, A. (2005). Karya Lengkap Abdullah bin Abdul Kadir Munsyi Jilid 1. Kepustakaan Populer Gramedia.

Sweeney, A. (2006). Abdullah Bin Abdul Kadir Munsyi: A Man of Bananas And Thorns. Indonesia and the Malay World, 34, 223-245.

Teeuw, A. (2015). Sastra dan Ilmu Sastra : Pengantar Teori Sastra. Pustaka Jaya.

Thompson, C. (2011). Travel Writing. New York: Routledge.

Van den Berg, L. W. . (2010). Orang Arab di Nusantara. Komunitas Bambu.

Van der Putten, J. (2006). Abdullah Munsyi and the missionaries. Journal of the Humanities and Social Sciences of Southeast Asia and Oceania, 162(4), 407440.

Yuliasari, H. (2013). Kisah Pelayaran Abdullah bin Abdulkadir Munsyi dari Singapura sampai ke Kelantan: Analisis Poskolonial. Skripsi. Universitas Gadjah Mada.

Zulikha, P. (2019). Agenda dan Ideologi dalam Novel Pelukis Gurun Pasir Karya Fuad Abdurahman: Analisis Sastra Perjalanan Carl Thompson. Skripsi. Universitas Gadjah Mada. 